\title{
Influence of Social Media on Tourists' Destination Selection Decision
}

\author{
Himangshu Shakor Paul ${ }^{1 *}$, Debashish Roy ${ }^{2}$, Raju $\mathrm{Mia}^{3}$ \\ ${ }^{1}$ Assistant Computer Programmer, Information and Communication Technology Cell, Sylhet Agricultural University, Bangladesh \\ ${ }^{2}$ Assistant Professor, Department of Business Administration, Metropolitan University, Sylhet, Bateshwar, Sylhet-3100, Bangladesh \\ ${ }^{3}$ Undergraduate Student, Department of Business Administration, Metropolitan University, Sylhet, Bateshwar, Sylhet-3100, Bangladesh
}

DOI: $10.36348 / \mathrm{sb} .2019 . \mathrm{v} 05 \mathrm{i} 11.009$

| Received: 19.11.2019 | Accepted: 26.11.2019 | Published: 30.11 .2019

*Corresponding author: Himangshu Shakor Paul

\section{Abstract}

Social media are interactive communication platform usually used for community-based inputs, content sharing, interaction and collaboration among people. Prominent social media platforms are, facebook, twitter, google+, wikipedia, LinkedIn etc. These social media channels serve as source of information and influence in decision-making process. Travel experience, photos, videos and other contents shared on social media may influence other prospective tourists in their destination selection decision. This study intended to discover the impact of social media on tourists' decision making. Data have been collected from 167 respondents using judgmental sampling technique. Collected data were analyzed using principle component analysis where 15 variables were reduced to two factors (social media information about destination and social media word-of-mouth). Further, the extent of influence of obtained factors on tourists' destination selection decision was identified using regression analysis and stated that these two factors explains $52.2 \%$ of the variance in data.

Keywords: Tourists' destination selection, social media, word-of-mouth, principle component analysis.

Copyright @ 2019: This is an open-access article distributed under the terms of the Creative Commons Attribution license which permits unrestricted use, distribution, and reproduction in any medium for non-commercial use (NonCommercial, or CC-BY-NC) provided the original author and source are credited.

\section{INTRODUCTION}

Due to the development of technology infrastructure and widespread availability of the internet have vastly changed consumer behavior. In recent days people take help from the internet to make there any kind of decision. As of June 30, 2019, around 58.8 percent of people of the world use the internet [1]. There are 4.39 billion internet users in 2019, an increase of 366 million (9 percent) versus January 2018. According to a study in 2019 around 3.48 billion people use social media and 3.26 billion of them use social media on mobile devices [2]. Social media is a set of the online communication channel used for the purpose of community-based input, interaction, content sharing and collaboration. Social media is becoming an integral part of life. Social media gained popularity in last few years because of its ability to share photos/ videos, opinions, events etc. in real time. Social media allow its subscriber with the opportunity to meet new people, join groups that share their interests, build up professional networking and so on. The use of social media as an information source has been increasing rapidly. People seek information in social media to identify alternatives, evaluate and make the decision.
Current study tries to explore the impact of social media in tourist destination selection decision.

Social media enabled each user to act as a communication vehicle. As people share their tourism related experiences, photos, videos, and other information on their social media account, these can serve as stimuli to other people on their network. Moreover the overall tourism industry (e.g. tour operators, hotels, resorts, restaurants, parks etc.) can access the benefit from the social media to promote their service. Different tourist destination authorities can confirm their exposure even at international level. The output of this study will enable tour destination business to better understand their prospect in terms of social media influence factor.

\section{LITERATURE REVIEW}

In recent age, the developments in information and communication technology (ICT) increased the social media usages which significantly influence consumer behavior and decision making [3] specifically during planning for travel or purchasing travel related products or services [4]. Gretzel, Kang, and Lee [5] 
Himangshu Shakor Paul et al., Sch Bull, Nov 2019; 5(11): 658-664

proposed that the influence of social media on individuals' tourism decision may increased dramatically. They denoted social media as a communication platform or channel that convey usergenerated contents and supplies travel related information which may guide prospective tourists. Presently, travelers uses social media to search for, evaluate, and select tourism destinations and spread travel stories and experiences. Social media enabled destination marketers to expand the reach of their communication messages to global audiences at a comparatively low costs. Most of the social media platforms enable their users to share their pictures, videos, comments and reviews which serve as source of information and testimonials [6]. Many travelers rely on other travelers' experiences shared on social media to know about the problems and facilities available in any destination [7, 8].

Tourism products are basically experiential; contain all the characteristics of services (i.e. intangible, variable, inseparable and perishable). Thus, it is difficult to evaluate the tourism products before purchase. As a result, decision making related to tourism is quite risky and require extensive information during information search phase of decision [9-12]. To reduce the risks associated with tourism decision making, travelers usually search for information in various sources of information [13, 14]. Due to the interactivity, customization capability and vastness world wide web became the popular source of information to the tourists for effective decision making [15]. However, all the information found in internet may not be reliable to tourists. Information from other travelers who already have experienced particular tourist destination seemed to be more reliable to the potential tourists [16]. Social media enable tourists to share travel experiences with their contacts. Due to the experiential nature of tourism, prospective tourist often rely on others experience shared on social media in their travel related decision making or destination selection to reduce risks or uncertainties [7] [17]. Social media play a vital role as a source of information in travel planning and tourist destination selection for potential travelers [6]. In selecting an unfamiliar destination to travel, tourism related blogs are found to be more helpful than friends and family [18, 19].

Along with the advancement in information technologies and social media platforms, major changes have also been observed in consumer behaviors in tourism industry. Changes in values and life styles, extended work schedule and shortened leisure period have made tourists more informed, more independent and more individualistic [20]. In cooperation with social media platforms, new technological advancements (i.e. Global positioning systems, high definition photo and video making devices, artificial intelligence etc.) have increased the volume and coverage of content sharing among travelers via social media applications. Thus social media and mobile technologies have significantly changed the tourist behavior [21].

Souza and Machado [22] examined the use of social media on different stages of trip planning. Their findings revealed that travelers use social media in all stages of trip planning as a reliable source of information. Sahin and Sengun [23] studied the importance of social media on tourism marketing. Their findings revealed that social media can affect tourism industry both positively and negatively and young generation is highly affected by contents shared by others on social media. Carnoy [24] stated that social media have significantly changed the way the travel companies communicate with their potential customers. The identified that social media have transformed the tourism marketing in five ways; i.e. travel research, social sharing, enhanced customer service, interactive travel agencies and changed tourist behavior. Olenski [25] mentioned that $20 \%$ of leisure tourists take help from social media sites in making their travel plan and destination selection. Kazak [26] also found a huge impact of social media in our daily decision making including the decisions related to travel and tourism. Dwityas and Briandana [27] also found that social media play an important role as an information source in travelers decision making and these information help travelers in every stages of decision making.

In another study, Li [28] stated that there is more chance of using social media in tour planning by tourists who expect to travel foreign countries. He also observed that tourists use social media not only as a source of information but also for recommendations and testimonials about tourism destinations. Similarly, Pike [29] mentioned that most of the modern travelers are technology savvy and 85 percent of prospective tourists rely on social media and internet. In the same vision, Minazzi [30] suggests that travel preparation stems from an internal need to gain new experience by traveling to a specific destination. Importantly, because of either internal or external stimuli, or both, this internal need can arise. Minazzi [30] therefore reiterates that visitors focus on meeting such a need by concentrating on finding the destination with a high potential to better meet such a need. In line with this, social media does indeed have a vital role to play in helping travelers find tourist goods and/or services that can meet these needs.

Various factors of social media, like trustworthiness, reliability and dependability were found to be important in tourists' decision making. Munar and Jacobsen [31] have found that tourists have high level of trust towards travel related review website. In addition to trustworthiness, other facets of the impact of social media on tourism that researchers and scholars have analyzed in the past include credibility or reliability. In this regard, one of the researchers ' concerns is whether travel consumers view social media as a credible and reliable tool for travel research and 
Himangshu Shakor Paul et al., Sch Bull, Nov 2019; 5(11): 658-664

planning [32]. Uysal, Perdue and Sirgy [32] noted that most travelers view social media as a reliable resource in providing a variety of information that might help them search and plan their travel. This is particularly the case in addition to the fact that in most cases the materials accessed via social media actually represents the current status of the destination(s) travelers are interested in. Moreover, through social media platforms, social media users can easily find critical information about their desired destination.

The number of users of social media continues to rise considerably. Most importantly, use of social media platform in tourism related decision making has also been increasing tremendously. This is because most of these people assume that social media offers a precise description of these destinations in terms of factors such as the products services and experiences they give their customers. Social media plays a key role in helping future visitors make informed choices about their destinations. Despite increasing work on the role of social media in the tourism industry, there are still areas to be adequately covered by researchers and scholars.

\section{Objective(s) of the Study}

In current era social media play a enormous role as a source of information for all kind of users for any kind of decision. The objective of the present study is to identify the factors of social media that influence tourists' destination selection decision. Moreover, this study will also gauge the extent of influence created by these factors.

\section{METHODOLOGY OF THE STUDY}

This study is mainly based on primary data collected through structured questionnaire. The survey was conducted through personal interview and online survey (via Google form). Judgmental sampling technique was applied and respondents were selected from several tourism spots (for personal interview) and travel related blogs and social media groups/pages (for online survey). Data have been collected from 167 respondents who used to travel regularly. Data collection period was from July 15, 2019 to August 10, 2019. Descriptive statistics were used to analyze the demographic profile of the respondents. Principle Component analysis has been applied to identify the factors of social media that influence tourists' destination selection decision and regression analysis was used to predict the influence of identified factors in tourist decision making. For analyzing data, SPSS-24 was used.

\section{Data Analysis and Findings}

Social media are tremendous source of information nowadays. Thus, tourists can use social media in their destination selection decision. The collected data to measure the impact of social media in tourists' decision have been analyzed in this section.

Table-1: Demographic profile of the respondents

\begin{tabular}{|c|c|c|c|}
\hline & Frequency & Percent \\
\hline \multirow[t]{2}{*}{ Gender } & Male & 106 & 63.5 \\
\hline & Female & 61 & 36.5 \\
\hline \multirow[t]{4}{*}{ Age Group } & Under 18 & 6 & 3.6 \\
\hline & 18-30 years & 149 & 89.2 \\
\hline & $30-45$ years & 11 & 6.6 \\
\hline & Above 45 & 1 & 0.6 \\
\hline \multirow[t]{2}{*}{ Marital Status } & Single & 146 & 87.4 \\
\hline & Married & 21 & 12.6 \\
\hline \multirow[t]{4}{*}{ Level of education } & Secondary & 5 & 3.0 \\
\hline & Higher secondary & 20 & 12.0 \\
\hline & Honors & 116 & 69.5 \\
\hline & Masters & 26 & 15.6 \\
\hline \multirow[t]{4}{*}{ Occupation } & Student & 133 & 79.6 \\
\hline & Service & 21 & 12.6 \\
\hline & Business & 6 & 3.6 \\
\hline & Others & 7 & 4.2 \\
\hline \multirow[t]{8}{*}{ Monthly family income } & Up to BDT. 10,000 & 14 & 8.4 \\
\hline & BDT. 10,000-20,000 & 31 & 18.6 \\
\hline & BDT. 20,000-30,000 & 32 & 19.2 \\
\hline & BDT. 30,000-40,000 & 22 & 13.2 \\
\hline & BDT. 40,000+ & 62 & 37.1 \\
\hline & Total & 161 & 96.4 \\
\hline & Missing-System & 6 & 3.6 \\
\hline & Total & 167 & 100.0 \\
\hline
\end{tabular}


Table-1 represents the demographic information of the respondents. Basically, demographic data is statistically collected data about the characteristics of population. The sample size of the study is 167 and majority of them were male. Besides, most of the respondents are from the age group of 18-30 years and about $80 \%$ of them are students.

\section{Principle Component Analysis}

To perform Principle Component Analysis (PCA), Kaiser-Meyer-Olkin (KMO) test of sampling adequacy is necessary. The KMO test is a measure of how the collected data is suited for carrying out factor analysis. The following Table-2, represents the KaiserMeyer-Olkin (KMO) and Bartlett's test of sphericity.

Table-2: KMO and Bartlett's Test of Sphericity

\begin{tabular}{|l|l|l|}
\hline Kaiser-Meyer-Olkin Measure of Sampling Adequacy. & $\mathbf{0 . 9 3 1}$ \\
\hline Bartlett's Test of Sphericity & Approx. Chi-Square & 1467.002 \\
\cline { 2 - 3 } & df & 105 \\
\cline { 2 - 3 } & Sig./ p-value & 0.000 \\
\hline
\end{tabular}

This table shows two tests that designate the suitability of collected data for structure detection. The KMO values range from 0 to 1 and a rule of thumb states that KMO values between 0.8 and 1 indicate the sample is adequate. Thus, from Table-2 we may conclude that the collected data is adequate for conducting PCA. Bartlett's test of sphericity is another indicator to measure the strength of relationship among variables. This tests the null hypothesis that the correlation matrix is an identity matrix. The Table-2 shows the p-value for Bartlett's test of sphericity is 0.000 which is less than 0.05 . So, we may reject the null hypothesis and say that the correlation matrix is not an identity matrix.

Table-3: Communalities

\begin{tabular}{|l|l|l|}
\hline & Initial & Extraction \\
\hline Social media provides information about 'new tourism destinations' & 1 & 0.63 \\
\hline 'Tour reviews' of others in social media help me to select destination & 1 & 0.73 \\
\hline 'Comment' and 'Reply' in social media provides important information. & 1 & 0.52 \\
\hline 'Videos' shared on social media influence me to select any destination. & 1 & 0.70 \\
\hline 'Images' of tourism spots shared on social media attract me to visit that place. & 1 & 0.74 \\
\hline Information found on social media regarding tourism seems reliable to me. & 1 & 0.50 \\
\hline Social media help me to gather tourism cost related information. & 1 & 0.59 \\
\hline Social media help me to get travel route information. & 1 & 0.49 \\
\hline Safety and security issues tourism destination can be identified from social media. & 1 & 0.58 \\
\hline Problems or risks in tour destination can be pointed from social media. & 1 & 0.56 \\
\hline Social media can be helpful to know about the restaurant or food facilities. & 1 & 0.54 \\
\hline Idea about accommodation facilities can be obtained through social media. & 1 & 0.66 \\
\hline Social media provides information about transportation infrastructure. & 1 & 0.73 \\
\hline To select the best time to visit, social media helps me. & 1 & 0.64 \\
\hline Social media provides understanding about the culture and heritage. & 1 & 0.58 \\
\hline
\end{tabular}

Table-3 shows the communalities before and after extraction. Principle Component Analysis (PCA) follows the primary assumption that all the variance is common, thus, before extraction all the communalities are 1. The extraction column reflects the common variance in data structure. Extraction communalities are estimates of the variance in each variable accounted for by the factors in the factor solution. The communality values which are more than 0.5 should be considered further analysis. Hence, from Table- 3 the researchers considered all the variables for further analysis. 


\begin{tabular}{|l|l|l|}
\hline & $\begin{array}{l}\text { Social media } \\
\text { information } \\
\text { about } \\
\text { destination }\end{array}$ & $\begin{array}{l}\text { Social media } \\
\text { word-of- } \\
\text { mouth }\end{array}$ \\
\hline Social media provides information about transportation. & $\mathbf{0 . 8 0 8}$ & \\
\hline Idea about accommodation facilities can be obtained through social media. & $\mathbf{0 . 7 5 8}$ & \\
\hline Safety and security issues tourism destination can be identified from social media. & $\mathbf{0 . 7 3 8}$ & \\
\hline To select the best time to visit, social media helps me. & $\mathbf{0 . 7 1 9}$ & \\
\hline Problems or risks in any destination can be pointed from social media. & $\mathbf{0 . 7 1 8}$ & \\
\hline Social media provides understanding about the culture and heritage. & $\mathbf{0 . 7 1 0}$ & \\
\hline Social media help me to gather tourism cost related information. & $\mathbf{0 . 6 4 2}$ & \\
\hline Social media can be helpful to know the restaurant or food. & $\mathbf{0 . 5 8 8}$ & \\
\hline Social media help me to get travel route information. & $\mathbf{0 . 5 2 0}$ & \\
\hline Images' of tourism spots shared on social media attract me to visit that place. & & $\mathbf{0 . 8 0 4}$ \\
\hline Videos' shared on social media influence me to select any destination. & & $\mathbf{0 . 7 9 7}$ \\
\hline Tour reviews' of others in social media help me to select destination & & $\mathbf{0 . 7 7 6}$ \\
\hline Comment' and 'Reply' in social media provides important information. & & $\mathbf{0 . 7 0 5}$ \\
\hline Social media provides information about 'new tourism destinations' & & $\mathbf{0 . 6 4 6}$ \\
\hline Information found on social media regarding tourism seems reliable to me. & & $\mathbf{0 . 6 3 5}$ \\
\hline Initial Eigenvalues & 8.026 & 1.233 \\
\hline \% of Variance & 53.504 & 8.220 \\
\hline Reliability Statistics (Cronbach's Alpha) & 0.912 & 0.884 \\
\hline
\end{tabular}

Table-4 represents the rotated component matrix of factor analysis. 15 variables related to social media influence on destination selection have been précised into 2 factors; Social media information about destination and Social media word-of-mouth. Usually, tourists seek information about transportation, accommodation, safety and security, problems and risk, when to visit, culture and heritage, costing, food facilities and travel route related information on social media. These variables are termed under the factor 'Social media information about destination'. Since this factor has Eigenvalue 8.026, it explains more variance than a single variable. In fact, this factor explains 8.026 times than a single variable. Moreover, this factor explains $53.504 \%$ of total variance. The reliability (Cronbach's Alpha) of this factor is 0.912, suggesting that the items have relatively high internal consistency. The second factor extracted is 'Social media word-ofmouth' with Eigenvalue of 1.233 and $8.220 \%$ of total variance. The alpha coefficient for 6 items in this factor is 0.884 which also signifies the high level of internal consistency among the items in the factor.

\section{DISCUSSION}

In present era, social media are communication platform for heterogeneous population. Tourists' decision selection decision vastly depends on social media. From the above finding it can be articulated that social media can manipulate tourists' destination selection decision through 2 different approaches. Tourists collect information about transportation, routes, accommodation, food, costs, safety-security, risk and problems regarding a tourist destination to decide rationally. However, digital word-of-mouth spread over social media (i.e. in the form of 'images', 'videos', 'comments and reply' etc.) may insist tourists to decide cognitively.

\section{Regression Analysis}

A simple linear regression has been conducted to predict the role of social media in tourists' destination selection decision. The output of regression analysis has been presented in following tables.

Table-5: Model Summary

\begin{tabular}{|l|l|l|l|l|}
\hline Model & R & R Square & Adjusted R Square & Std. Error of the Estimate \\
\hline 1 & 0.723 & 0.522 & 0.516 & 0.715 \\
\hline \multicolumn{4}{|l|}{ Predictors: (Constant), Social media word-of-mouth, Social media information about destination } \\
\hline
\end{tabular}

Table-5 represents the model summary of regression analysis. Here, the term $\mathrm{R}$ denotes correlation between regressor variable (role of social media in tourist destination selection) and regressand variable (Social media information about destination and Social media word-of-mouth). Here the value of $\mathrm{R}$ is 0.723 , which means there is high correlation exists between regressor and regressand. In this model, calculated $\mathrm{R}$ square value is 0.522 this mean the linear regression explains $52.2 \%$ of the variance in data. 
Himangshu Shakor Paul et al., Sch Bull, Nov 2019; 5(11): 658-664

Table-6: ANOVA

\begin{tabular}{|l|l|l|l|l|l|l|}
\hline Model & & Sum of Squares & df & Mean Square & F & Sig. \\
\hline \multirow{3}{*}{1} & Regression & 88.260 & 2 & 44.130 & 86.364 & $.000(\mathrm{a})$ \\
\cline { 2 - 5 } & Residual & 80.734 & 158 & .511 & & \\
\cline { 2 - 5 } & Total & 168.994 & 160 & & \\
\hline
\end{tabular}

The Table- 6 represents the F-test. The linear regressions' F-test has the null hypothesis that the model explains 'zero' variance (i.e. $\mathrm{R}^{2}=0$ ). Here the Ftest is highly significant, thus it can be assumed that the model explains significant amount of variance in 'role of social media in tourist destination selection decision'. In other words, it can be concluded that the current regression equation meaningfully describe the relationship between dependent and independent variables.

Table-7: Coefficients

\begin{tabular}{|l|l|l|l|l|l|l|}
\hline \multirow{2}{*}{ Model } & & $\begin{array}{l}\text { Unstandardized } \\
\text { Coefficients }\end{array}$ & $\begin{array}{l}\text { Standardized } \\
\text { Coefficients }\end{array}$ & t & Sig. \\
\cline { 3 - 7 } & & B & Std. Error & Beta & B & Std. Error \\
\hline \multirow{3}{*}{1} & 3.994 & .056 & & 70.892 & .000 \\
\cline { 2 - 7 } & $\begin{array}{l}\text { Social media information } \\
\text { about destination }\end{array}$ & 0.332 & .057 & .323 & 5.881 & .000 \\
\cline { 2 - 7 } & Social media word-of-mouth & 0.664 & .057 & .646 & 11.753 & .000 \\
\hline \multicolumn{6}{|l|}{ Dependent Variable: Role of social media in tourist destination selection decision } \\
\hline
\end{tabular}

The coefficient table provides the necessary information to predict the role of social media in tourist destination selection from 'Social media information about destination' and 'Social media word-of-mouth' as well as these independent variables contributes statistically significantly to the model. From the Table7 , the estimated regression coefficients are: $\beta_{0}=3.994$, $\beta_{1}=0.332$ and $\beta_{2}=0.664$. Therefore, following regression equation can be proposed:

Role of social media in tourist destination selection decision=3.994+0.332 (Social media information about destination) +0.664 (Social media word-of-mouth) + error term

\section{CONCLUSION}

The purpose of the study was to identify the various issues of social media that can influence tourists' decision making. As social media are widely used source of information, tourists use these media in their decision making process. Social media provide information about transportation facilities, travel routes, accommodation and restaurant facilities, problems and risks, safety issues, culture and heritage of tourist destinations. Moreover, social media also perform as a word-of-mouth communication tool in tourist decision making. In present business world, the power of social media can be utilized by the tourism industry to attract, retain and grow the number of visitors in their destinations. The outcome of this study can be applied by the decision makers of many businesses which are related with tourism industry (i.e. transportation companies, travel agencies, hotels, restaurants etc.). However, this study analyzed the impact of overall social media on tourists' decision making. Further study can be conducted focusing on specific social media vehicle (e.g. facebook, twitter, youtube).

\section{REFERENCES}

1. Internet world stats (https://internetworldstats.com/stats.htm). retrieved at 7:55 pm, 25 July, 2019

2. The next web (https://thenextweb.com/contributors/2019/01/30/d igital-trends-2019-every-single-stat-you-need-toknow-about-the-internet/). retrieved at 7:59 pm, 25 July, 2019

3. Buhalis, D. (1998). Strategic use of information technologies in the tourism industry. Tourism Management, 19(5):409-421.

4. Buhalis, D., \& Law, R. (2008). Progress in information technology and tourism management: 20 years on and 10 years after the internet-The state of e-tourism research. Tourism Management, 29(4):609-623.

5. Gretzel, U., Kang, M. H., \& Lee, W. J. (2008). Differences in consumer-generated media adoption and use a cross-national perspective. Journal of Hospitality \& Leisure Marketing, 17(12), 99-120.

6. Xiang, Z., \& Gretzel, U. (2010). Role of social media in online travel information search. Tourism Management, 31(2):179-188.

7. Litvin, S. W., Goldsmith, R. E., \& Pan, B. (2008). Electronic word-of-mouth in hospitality and tourism management. Tourism Management, 29(3):458-468.

8. Kotler, P., Bowen, J., \& Makens, J. C. (2010). Marketing for hospitality and tourism (5th ed.). Boston, MA: Pearson Education. 
Himangshu Shakor Paul et al., Sch Bull, Nov 2019; 5(11): 658-664

9. McIntosh, R. W., Goeldner, C. R., \& Ritchie, J. R. B. (1995). Tourism: principles, practices, philosophies (7th ed.). New York: Wiley.

10. Holloway, J. C. (2004). Marketing for tourism. (4th ed.). Harlow: Financial Times Prentice Hall.

11. Middleton, V. T. C., Fyall, A., Morgan, M., \& Ranchhod, A. (2009). Marketing in travel and tourism. (4th ed.). Oxford: ButterworthHeinemann.

12. [12] Huang, C., Chou, C., \& Lin, P. (2010). Involvement theory in constructing bloggers' intention to purchase travel products. Tourism Management, 31(4):513-526.

13. Gursoy, D., \& Mc Cleary, K. W. (2004). An Integrative Model of Tourists' Information Search behavior. Annals of Tourism Research, 31(2):353373.

14. Chung, Y., \& Buhalis, D. (2008). Information Needs in Online Social Networks. Information Technology \& Tourism, 10(4):267-281.

15. Werthner, H., \& Klein, S. (1999). Information Technology and Tourism-A challenging relationship. New York: Springer.

16. Crotts, J. (1999). Consumer decision making and pre-purchase information search. Consumer Behavior in Travel and Tourism, 149-168.

17. Yoo, K. H., Lee, K. S., \& Gretzel, U. (2007). The role of source characteristics in eWOM: What makes online travel reviewers credible and likeable? Information and Communication Technologies in Tourism, 23-34.

18. Tan, W. K., \& Chen, T. H. (2012). The usage of online tourist information sources in tourist information search: An exploratory study. Service Industries Journal, 32(3), 451-476.

19. Lee, Y. J., \& Gretzel, U. (2014). Cross-Cultural Differences in Social Identity Formation. through Travel Blogging. Journal of Travel \& Tourism Marketing, 31(1):37-54.

20. Poon, A. (1993). Tourism, technology and competitive strategies. Wallingford: $\mathrm{CAB}$ International.

21. Xiang, Z., Magnini, V. P., \& Fesenmaier, D. R. (2015). Information technology and consumer behavior in travel and tourism: Insights from travel planning using the internet. Journal of Retailing and Consumer Services [online], In Press. Available
http://www.sciencedirect.com/science/article/pii/S

$0969698914001131 \quad$ [Accessed

30

September, 2019]

22. Souzaa, S. C., \& Machadob, D. F. C. (2017). Use and Influence of Social Media on Trip Planning: a quantitative study. Revista Turismo em Análise RTA, 28(2), 25-270.

23. Sahin, G. G., \& Sengun, G. (2015). The Effect of Social Media on Tourism Marketing: A Study among University Students. Management and Administrative Sciences Review, 4(5), 772-786.

24. Carnoy, J. (2017). 5 Ways Social Media Has Transformed Tourism Marketing. Entrepreneur. [Available https://www.entrepreneur.com/article/286408]

25. Olenski, S. (2014). The Impact of Social Media in the Travel Marketing Industry. Forbes. [Available at:

https://www.forbes.com/sites/steveolenski/2014/0 2/07/the-impact-of-social-media-in-the-travelmarketingindustry/\#3de88d7e2ad3]

26. Kazak, L. (2016). The Impact of Social Media on the Tourism Industry. [Available at: https://www.linkedin.com/pulse/impact-socialmedia-tourism-industry-liudmila-kazak]

27. Dwityas, N. A., \& Briandana, R. (2017). Social Media in Travel Decision Making Process. International Journal of Humanities and Social Science, 7(7), 193-201.

28. Li, X. (2016). Chinese outbound tourism 2.0 (Advances in hospitality and tourism). Boca Raton, FL: CRC Press.

29. Pike, S. (2016). Destination marketing: Essentials. New York: Routledge.

30. Minazzi, R. (2014). Social media marketing in tourism and hospitality. New York: Springer Cham Heidelberg.

31. Munar, A. M., \& Jacobsen, J. K. S. (2013). Trust and involvement in tourism social media and web-based travel information sources. Scandinavian Journal of Hospitality and Tourism, 13(1), 1-19.

32. Uysal, M., Perdue, R., \& Sirgy, J. (2012). Handbook of tourism and quality-of-life research: Enhancing the lives of tourists and residents of host communities. New York: Springer Science \& Business Media. 